\title{
PENGGUNAAN LEMBAR KERJA SETING KOMIK DALAM MENINGKATKAN PRESTASI BELAJAR MATEMATIKA SISWA SEKOLAH DASAR
}

\author{
Husen Windayana; Dudung Priatna; Entang Kartika ${ }^{1}$
}

\begin{abstract}
ABSTRAK
Penelitian ini dilatarbelakangi oleh rendahnya prestasi belajar serta kurangnya minat siswa sekolah dasar dalam belajar matematika. Tujuan penelitian ini untuk mengetahui seberapa besar Lembar Kerja Seting Komik dapat meningkatkan prestasi belajar matematika siswa dan mendorong sikap belajar siswa terhadap matematika, mengingat siswa sekolah dasar senang dengan buku-buku bergambar. Penelitian menggunakan metode kuasi eksperimen dengan kelas kontrol. Instrumen penelitian yang dipakai menggunakan soal tes dan skala sikap Lickert yang diujicoba terlebih dahulu. Hasil penelitian menunjukan bahwa Lembar Kerja Seting Komik meningkatkan prestasi belajar matematika siswa. Secara signifikan terdapat perbedaan prestasi belajar antara siswa yang belajarnya dengan Lembar Kerja Seting Komik dengan yang basa. Hal tersebut ditunjukkan oleh rerata nilai postes kelompok eksperimen sebesar 80,94 dan hanya sebesar 67,03 pada kelompok kontrolnya. Kemudian ada perbedaan sikap belajar yang signifikan antara kelompok siswa yang belajarnya menggunakan Lembar Kerja Seting Komik dibandingkan kelompok siswa yang belajarnya biasa. Kelompok siswa yang belajarnya dengan Lembar Kerja Seting Komik memiliki sikap belajar yang lebih baik dibandingkan kelompok siswa yang belajarnya biasa.
\end{abstract}

Kata kunci: lembar kerja seting komik, prestasi belajar, dan sikap belajar

\section{A. PENDAHULUAN}

Matematika masih dipandang sebagai salah satu mata pelajaran yang kurang disukai oleh sebagian besar siswa, dikarenakan matematika dianggap sebagai mata pelajaran yang sulit. Kekurang sukaan siswa terhadap mata pelajaran matematika tentunya akan berimbas terhadap rendahnya prestasi belajar. Kekurang sukaan tersebut salah satunya disebabkan oleh penyajian bahan ajar yang tidak menarik minat belajar siswa. Padahal di sisi lain, karakteristik siswa sekolah dasar, salah satunya masih menyukai bahan ajar yang berbentuk gambar. Umumnya hampir semua siswa sekolah dasar menyukai bahan ajar yang berbentuk gambar, termasuk gambar-gambar bercerita layaknya komik.

Ketersediaan bahan ajar yang sesuai dengan kebutuhan belajar siswa sangat kurang. Bahan ajar yang dapat membimbing guru untuk dapat mempraktekan kegiatan belajar mengajar sesuai prinsip-prinsip belajar siswa aktif jarang didapatkan. Umumnya bahan ajar yang ada, terkemas dalam bentuk buku pelajaran

${ }^{1}$ Dosen Universitas Pendidikan Indonesia Kampus Cibiru 
biasa yang tidak membuat guru mudah dalam mempraktekan kegiatan belajar mengajar sesuai prinsip-prinsip belajar aktif dan bermakna.

Atas dasar pandangan di atas, dapat dikemukakan beberapa pertanyaan berikut.

1. Apakah ada perbedaan prestasi belajar matematika siswa antara kelompok perlakuan yang belajarnya menggunakan Lembar Kerja Seting Komik dengan prestasi belajar siswa pada kelompok kontrol yang belajarnya biasa?

2. Apakah ada perbedaan sikap belajar siswa terhadap mata pelajaran matematika ketika belajarnya menggunakan bahan ajar Lembar Kerja Seting Komik dengan yang belajarnya biasa?

Adapun tujuan yang ingin dicapai melalui penelitian ini adalah sebagai berikut,

1. Mendeskripsikan signifikansi perbedaan prestasi belajar matematika siswa antara yang belajar menggunakan Lembar Kerja Seting Komik dengan yang belajarnya biasa.

2. Mendeskripsikan signifikansi perbedaan sikap belajar siswa terhadap matematika ketika belajarnya menggunakan Lembar Kerja Seting Komik dibandingkan yang belajarnya biasa.

\section{B. TINJAUAN TEORITIS}

Hers (Program Pendidikan Matematika, 2000) dengan pandangan modernya mengatakan bahwa matematika adalah ide-ide, tidak ada coretan pensil atau kapur, tidak ada bentuk fisik seperti segitiga, tetapi hanya berupa ide-ide abstrak. Sekalipun terdapat obyek-obyek fisik, itu hanya sebatas untuk kebutuhan representasi, yang tidak sama dengan keadaan konsep sebenarnya. Matematika adalah disiplin ilmu yang obyeknya abstrak tidak dalam bentuk fisik, serta matematika telah berkembang secara pesat dengan menghasilkan berbagai cabang.

Menurut pandangan Hudoyo (1997), yang sejalan dengan pendapat Ruseffendi (1980), bahwa, karakteristik matematika berkenaan dengan ide-ide, struktur-struktur, dan hubungan-hubungan yang tersusun secara teratur, serta tersajikan secara logis. Hal ini memberi gambaran bahwa, sebagai sebuah ide, matematika menyajikan gagasan-gagasan dalam bentuk pernyataan-pernyataan yang terorganisasi, sistematis dan logis. Matematika adalah rangkaian ide yang tersusun secara teratur antara satu dengan yang lainnya. Ide-ide dalam matematika adalah konsep-konsep abstrak yang logis dan tersajikan ke dalam bentuk-bentuk simbul formal. Simbul-simbul adalah bahasa matematika yang bersifat universal, sebagai sebuah kesepakatan yang disepakati secara umum.

Media pembelajaran yang sesuai dengan kebutuhan belajar siswa akan berpengaruh terhadap efektifitas pembelajaran. Seperti dikatakan Brown (Sudrajat, Akhmad, 2008) bahwa, media pembelajaran yang digunakan dalam kegiatan belajar mengajar dapat mempengaruhi efektifitas pembelajaran.

Komik adalah buku yang berisi penuh dengan gambar-gambar dan bercerita tentang suatu tema. Gambar-gambar yang ditampilkan dilengkapi dengan dialog yang runtut dan teratur. Komik umumnya disukai oleh anak maupun orang dewasa. Karena komik mampu membimbing pembaca untuk melakukan imajinasi dan mengembangkan khayalannya sesuai alur cerita yang tersajikan. Di samping itu, 
komik yang tertuangkan dalam bentuk gambar mudah dimengerti. Oleh karena itu komik disukai oleh anak maupun orang dewasa.

Komik telah menjadi media yang dimanfatkan untuk kebutuhan pembelajaran di Amerika sekitar tahun 70-an, walaupun akhirnya ditarik kembali karena menerima bebagai protes dari banyak kalangan. Namun tidak berapa lama, sekitar tahun 80-an komik kembali dimanfaatkan sebagai media belajar. Misalnya Campbell, Richard W; Schoof, Robert (Blog, diposting 2012), menyatukan komik ke dalam sebuah program membaca bagi siswa dan komik berguna untuk pelajaran bahasa khususnya untuk pelajaran dialek dan karakterisasi.

Menurut Yang, Gene (Blog, diposting 2012) komik memiliki beberapa kelebihan, yaitu, 1) mampu memotivasi belajar siswa dan mampu meningkatkan partisipasi individu, 2) gambar pada komik dapat meningkatkan kualitas proses dan hasil pembelajaran, 3) komik dapat membuat pemahaman yang lebih permanen, karena melalui lembaran-lembaran komik siswa dapat mengulangi membaca hal-hal yang belum dipahaminya. 4) komik sebagai media perantara untuk membentuk keterampilan membaca serius, dan komik sebagai jembatan dari tidak suka membaca menjadi gemar membaca.

Lembar Kerja Seting Komik (LKSK) adalah media perantara yang digunakan untuk menyampaikan konsep-konsep matematika melalui gambar-gambar bercerita. LKSK berbentuk lembaran-lembaran kertas yang penuh dengan gambar-gambar bercerita, layaknya komik, dan di dalamnya memuat konsep-konsep matematika. Gelembung-gelembung dialog adalah alur cerita yang berisikan konsep-konsep matematika yang dipelajari sisiwa.

\section{METODE PENELITIAN}

Penelitian menggunakan desain kuasi eksperimen pretes-postes kelas kontrol. Kelompok pertama adalah kelas yang menerima perlakuan pembelajaran menggunakan Lembar Kerja Seting Komik, sebagai kelas treatmen, dan satu kelompok lain adalah kelas yang memperoleh perlakuan pembelajaran biasa, sebagai kelas kontrol.

Populasi penelitian ini adalah seluruh siswa kelas 4 sekolah dasar yang ada di SD Laboratorium UPI Kampus Cibiru sebanyak 175 orang, tersebar ke dalam 7 kelas paralel. Sedangkan sampelnya adalah siswa kelas 4 sebanyak empat kelas, yang terbagi ke dalam 2 kelas sebagai kelompok perlakuan dan 2 kelas sebagai kelompok kontrol. Kelompok kontrol dan kelompok perlakuan adalah kelas-kelas dimana siswanya memiliki kemampuan homogen, dengan komposisi siswa laki-laki dan permpuan seimbang. Sedangkan subyek penelitiannya adalah seluruh siswa yang terdapat di empat kelas, baik di kelas perlakuan maupun siswa yang ada di kelas kontrol.

Instrumen penelitian yang dikembangkan dalam mendukung kegiatan penelitian ini adalah soal tes, skala sikap untuk siswa, dan lembar observasi, serta catatan lapangan. Instrumen pengumpul data yang berkenan dengan soal tes sebelum digunakan diuji coba terlebih dahulu untuk melihat reliabilitas, validitas item, tingkat kesukaran, dan daya pembeda. 


\section{HASIL DAN PEMBAHASAN}

\section{Kemampuan Awal Matematika Siswa}

Kemampuan awal matematika siswa dari kelompok eksperimen adalah 29,20 dan kelompok kontrol sebesar 30,16. Rerata kemampuan awal matematika siswa dari kedua kelompok tersebut memiliki selisih sebesar 0,96. Kemampuan awal siswa pada penguasaan konsep-konsep matematika setelah dilakukan uji signifikansi melalui Uji Mann-Whitney diperoleh tidak berbeda. Karena nilai $p$-value $=0,919$ lebih besar dari $a=0,05$ maka Ho tidak ditolak. Median kedua kelompok, yaitu kelompok eksperimen dan kelompok kontrol tidak berbeda secara signifikan.

\section{Kemampuan Akhir Matematika Siswa Setelah Perlakuan}

Kemampuan akhir matematika siswa setelah dilakukan perlakuan pada kelompok eksperimen yang menggunakan pembelajaran dengan memanfaatkan media Lembar Kerja Seting Komik secara signifikan lebih baik dibandingkan kelompok siswa yang belajarnya dengan cara biasa. Hal tersebut ditampilkan oleh rerata kemampuan akhir matematika siswa pada kelompok eksperimen sebesar 80,94 dengan simpangan baku 4,66 dibandingkan rerata kemampuan akhir matematika siswa pada kelompok kontrol sebesar 67,03 dengan simpangan baku 6,58 .

Melalui uji perbedaan kemampuan dengan uji Mann-Whitney memberikan nilai $Z=-6,524$ dengan nilai $p$-value $=0,000$ untuk uji dua sisi. Karena nilai $p$-value $=$ 0,000 lebih kecil dari $a=0,005$ maka hipotesis nol ditolak. Disimpulkan bahwa kemampuan akhir matematika siswa pada kelompok eksperimen tidak sama dengan kemampuan matematika siswa pada kelompok kontrolnya. Kemampuan akhir matematika siswa pada kelompok eksperimen lebih baik dibandingkan kemampuan akhir matematika siswa pada kelompok kontrolnya.

Terjadinya peningkatan kemampuan matematika terhadap konsep-konsep yang dipelajari siswa, dari kemampuan awal sebesar 29,20 menjadi 80,94 diantaranya disebabkan Lembar Kerja Seting Komik mampu mendorong siswa untuk belajar terfokus pada konsep yang tertuang pada lembar kerja. Siswa secara serius dan antusias mempelajari langkah-demi langkah cerita bergambar yang di dalamnya mengandung konsep-konsep matematika. Kemudian dari hasil menyimak cerita tersebut dilanjutkan dengan siswa menceritakan kembali yang dipahaminya melalui presentasi kelompok. Kegiatan belajar mandiri yang mengandalkan kemampuan menyimak sendiri seperti itu yang kemudian dilanjutkan dengan presentasi kelompok, membuat siswa merasa bermakna dalam setiap mempelajari konsepkonsep matematika yang diajarkan. Antusiasme siswa terhadap belajar dengan Lembar Kerja Seting Komik tercermin dari setiap akhir pembelajaran. Hampir sebagian besar siswa meminta pelajaran matematika yang akan datang juga menggunakan Lembar Kerja Seting Komik. Malah beberapa siswa meminta agar ceritanya diformat ke dalam konflik yang lebih tajam. Hal ini yang memberi gambaran bahwa penggunaan Lembar Kerja Seting Komik mampu memberi kesan positif terhadap belajar siswa. 


\section{Sikap Belajar}

Sikap belajar siswa terhadap matematika yang dikumpulkan melalui angket dari kelompok eksperimen dan kelompok kontrol diperoleh masing-masing rerata 3,8 dan 3,2. Sikap belajar siswa pada kelompok eksperimen menunjukkan kecenderungan ke arah positif dibandingkan sikap belajar siswa pada kelompok kontrol. Melalui uji $\mathrm{t}$ diperoleh secara signifikan terdapat perbedaan sikap belajar siswa antara kelompok yang belajarnya menggunakan Lembar Kerja Seting Komik dengan kelompok siswa yang belajarnya biasa. Kelompok siswa yang belajarnya menggunakan Lembar Kerja Seting Komik memiliki sikap belajar yang lebih baik dibandingkan kelompok siswa yang belajarnya dengan cara biasa.

Sikap belajar yang positif seperti tersebut di atas ditunjang oleh temuantemuan ketika berlangsungnya proses belajar mengajar di kelas, seperti suasana belajar di kelas teramati hening ketika siswa membaca dan menyimak Lembar Kerja Seting Komik. Siswa terlihat antusias ketika diminta oleh guru menceritakan isi cerita yang terdapat pada Lembar Kerja Seting Komik di depan kelas, serta siswa terlihat bersemangat ketika bekerja dalam kelompok menyelesaikan soal-soal terkait konsep yang terdapat pada Lembar Kerja Seting Komik tersebut. Di akhir pelajaran beberapa siswa meminta agar konflik yang terdapat pada cerita untuk diperbanyak dan dipertajam, supaya lebih mengasyikan. Dari deskripsi tersebut nampak bahwa media Lembar Kerja Seting Komik mampu mendorong sikap belajar siswa ke arah yang lebih baik.

\section{E. KESIMPULAN DAN REKOMENDASI}

Beberapa hal yang dapat disimpulkan dari hasil penelitian adalah,

1. Penggunaan Lembar Kerja Seting Komik dapat meningkatkan prestasi belajar siswa dan berbeda secara signifikan dibandingkan kelompok siswa yang belajarnya biasa. Hal tersebut ditunjukkan oleh rerata nilai postes kelompok eksperimen sebesar 80,94 dan hanya sebesar 67,03 pada kelompok kontrolnya.

2. Penggunaan Lembar Kerja Seting Komik dapat mendorong siswa memiliki sikap belajar yang lebih baik. Secara signifikan sikap belajar matematika siswa yang menggunakan Lembar Kerja Seting Komik lebih baik dibandingkan yang belajarnya biasa.

Ada beberapa rekomendasi yang dapat diajukan sekaitan dengan penelitian ini. Rekomendasi tersebut adalah sebagai berikut.

1. Penggunaan Lembar Kerja Seting Komik dapat meningkatkan prestasi dan sikap belajar matematika siswa pada topik-topik yang diajarkan dibandingkan yang belajarnya biasa. Oleh karena itu penggunaan Lembar Kerja Seting Komik menjadi salah satu alternative yang dapat digunakan guru untuk pembelajaran matematika di kelas.

2. Sebaiknya dilakukan penelitian lanjut, untuk melihat sejauh mana keefektifan penggunaan media gambar komik dalam pembelajaran matematika bila dibandingkan dengan media cerita narasi biasa. 


\section{DAFTAR PUSTAKA}

Blog (2012). Komik Sebagai Media Pembelajaran. Posted 2011.

Cangelosi, James S. (1990). Merancang Tes Untuk Menilai Prestasi Siswa. Bandung ITB Bandung.

Dewanti, AY. (2011). Pengaruh Penggunaan Media Komik Strip Terhadap Hasil Belajar IPA Siswa Kelas 5 Di SDN Purwodadi 1 Malang. Malang: UNM.

Fitriyanto, Hari (2011). Perbedaan Hasil Belajar Siswa Pada Pembelajaran Matematika Mengunakan Media Komik Dengan Yang Biasa. Bandung: Skripsi UPI Kampus Cibiru.

Haryadi, Dian (2008). Komik Sebagai Media Pembelajaran Matematika. Postingan.

Hudoyo (1997). Pendidikan Matematika. Malang: UNM.

Marat (1984). Sikap Manusia Perubahan Serta Pengukurannha. Jakarta: Ghalia Indonesia.

Maulana (2008). Komik Sebagai Media Pembelajaran Matematika. Bandung: UPI.

Peryoga, Ikhsan (2011). Komik Sebagai Media Pembelajaran Sejarah. Posted 9 November 2011.

Ruseffendi, E. T. (1994). Dasar-dasar Penelitian Pendidikan Dan Bidang Non-Eksakta Lainnya. Semarang: IKIP Semarang Press.

Ruseffendi, E. T. (1998). Statistika Dasar Untuk Penelitian Pendidikan. Bandung: IKIP Bandung Press.

Sudrajat, Ahmad (2008). Media Pembelajaran. Posted 12 Januari 2008.

Suherman, E dan Sukjaya, Y (1990). Evaluasi Pendidikan Matematika. Bandung: Wijayakusumah 157.

Uyanto, Stanislaus S. (2009). Pedoman Analisis Data Dengan SPSS. Yogyakarta: Graha Ilmu.

Windayana, Husen (2002). Perbandingan Kemampuan Siswa Sekolah Dasar Dalam Membei Alasan Logis Antara Yang Memperoleh Pembelajaran Matematika Teknik Probing Dengan Yang Biasa. Tesis. Tidak Diterbitkan. Bandung: Program Pasca Sarjana UPI.

Windayana, Husen (2009). Pembelajaran Matematika Kontekstual Kelompok Permanen dan Tidak Permanen Dalam Meningkatkan Kemampuan Penalaran dan Komunikasi Matematik Siswa Sekolah Dasar. Disertasi. Tidak Diterbitkan. Bandung: Program Pasca Sarjana UPI. 